CATALLAXY

Volume 2 Issue 1 June 2017

e-ISSN 2544-090X

ऽ www.catallaxy.pl

Oryginalny artykut naukowy

otrzymano: 14.05.2017 / zaakceptowano: 28.06.2017 / opublikowano online: 30.06 .2017

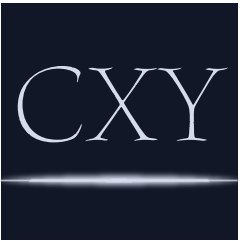

()ㅜㅇㅜ

Pisany, P., i Dejneka, W. (2017). Europejska Unia Rynków Kapitałowych a zróżnicowanie systemów finansowych państw członkowskich. Catallaxy, 2(1): 13-25. doi:10.24136/cxyv2i1.2.

\title{
Europejska Unia Rynków Kapitałowych a zróżnicowanie systemów finansowych panstw członkowskich
}

\section{PAWEE PISANY}

autor korespondencyjny

Kolegium Gospodarki Światowej, Szkoła Gtówna Handlowa w Warszawie, al. Niepodległości 162, 02-554 Warszawa, Polska

๑ppisany@gmail.com

(D) orcid.org/0000-0001-9665-8840

WOJCIECH DEJNEKA

Szkoła Gtówna Handlowa w Warszawie (absolwent)

曰wojciech.dejneka@gmail.com

(iD) orcid.org/0000-0002-6020-8001

\begin{abstract}
Abstrakt
Motywacja: Europejska Unia Rynków Kapitałowych (European Capital Markets Union - CMU) jest ważnym i szeroko zakrojonym projektem mającym na celu poprawę konkurencyjności gospodarki Unii Europejskiej (UE). Najważniejszymi celami planowanych reform są: poprawa dostępu europejskich przedsiębiorstw do długoterminowego finansowania, głównie w przypadku start-upów oraz sektora małych i średnich przedsiębiorstw (MSP), a także zwiększenie różnorodności dostępnych dla firm metod finansowania poprzez rozwój rynków instrumentów właścicielskich (akcji), a także korporacyjnych instrumentów dłużnych.

Cel: Głównym celem artykułu jest przedstawienie CMU na tle literatury odwołującej się do mechanizmów zmian strukturalnych w systemach finansowych oraz w kontekście obecnego kształtu europejskiego sektora finansowego. W rezultacie zostanie dokonana ocena CMU oraz zostaną wyszczególnione najważniejsze ograniczenia, z jakimi może spotkać się unijne prawodawstwo, podczas prac nad CMU.

Wyniki: Zasięg planowanych reform stanowi zasadnicze wyzwanie ze względów prawnych (różny stopień harmonizacji różnych gałęzi prawa w UE), politycznych (konieczność głębszej integracji UE), a także z powodu zróżnicowania systemów finansowych w państwach UE. Jednocześnie jednak, w świetle badań, m.in. B. Amable (2003) nad komplementarnością instytucjonalną, zakres skutecznych reform systemu finansowego musi być rozległy i obejmować zarówno stronę popytową, jak i podażową. Selektywne sięganie do doświadczeń państw anglosaskich w tym zakresie wydaje się uzasadnione, tym bardziej, że analizy ilościowe wskazują na dużą przestrzeń dla rozwoju rynków finansowych w UE.
\end{abstract}

Stowa kluczowe: rynek kapitatowy; regulacje; Unia Europejska

JEL: G15; G18 


\section{Wprowadzenie}

Głównym celem artykułu jest przedstawienie funkcjonowania Europejskiej Unii Rynków Kapitałowych (European Capital Markets Union - CMU) na tle literatury odwołującej się do mechanizmów zmian strukturalnych $\mathrm{w}$ systemach finansowych oraz $\mathrm{w}$ kontekście obecnego kształtu europejskiego sektora finansowego.

W Sekcji 2. dokonana została ocena wyzwań stojących przed Unią Europejską (UE) i stanowiących tło podjętych działań w zakresie stworzenia CMU, której kształt i założenia zostały szerzej omówione w Sekcji 3. W Sekcji 4. przedstawionych zostało szczegółowo sześć grup inicjatyw planowanych w ramach CMU. Przeprowadzona w Sekcji 5. komparatystyka projektowanej CMU z istniejącą już unią bankową, pozwala $z$ kolei ocenić zarówno komplementarność obu projektów, jak i uwarunkowania determinujące różny charakter regulacji. W Sekcji 6. przedstawione zostały wyzwania oraz ograniczenia, $z$ jakimi może spotkać się unijny prawodawca podczas prac nad CMU.

\section{Identyfikacja wyzwania}

Jednym z głównych wyzwań dla UE jest obecnie poprawa konkurencyjności gospodarki, zwłaszcza w obliczu rozwoju nowych, ważnych ośrodków gospodarczych takich, jak Indie, czy Chiny oraz pobudzenie wzrostu gospodarczego. Wystąpienie sekularnej stagnacji, tzn. przedłużającego się okresu niskiego tempa wzrostu gospodarczego, nierosnącej produkcyjności, spadających inwestycji, niskiej inflacji oraz niskich stóp procentowych $w$ gospodarce UE, jest często wskazywane, jako bardzo istotny problem i tym samym wyzwanie dla europejskich liderów politycznych (Pichelmann, 2015; Mączyńska, 2015). Realizacja szeroko zakrojonej polityki prorozwojowej mogłaby też pomóc w zmniejszeniu bezrobocia, zwłaszcza wśród ludzi młodych. W niektórych państwach UE takich, jak Hiszpania, brak pracy dla absolwentów stanowi kluczowe zadanie dla polityków, zarówno ze względów gospodarczych, jak i społecznych.

W kontekście przytoczonych wyzwań, ważna będzie rola europejskiego systemu finansowego. Konieczne jest zmobilizowanie kapitału dla rozwoju, połączenie nadwyżkowych środków u potencjalnych inwestorów $z$ przedsiębiorcami. Wydaje się, że funkcjonujące obecnie zasady, realizujące swobodę przepływu kapitału zawartą $\mathrm{w}$ art. 26 pkt. 2 oraz art. 63 Traktatu o funkcjonowaniu Unii Europejskiej (1957), są niewystarczające. Tworzą one możliwości transgranicznych inwestycji. Jednak wobec wyzwań, przed jakimi stanęła UE, potrzebne będzie stworzenie odpowiednich zachęt i ułatwień - aktywne wspieranie integracji $w$ obszarze finansów, m.in. przez uproszczenie wymogów emisyjnych, lecz nie tylko.

Problematyka związana $z$ najefektywniejszym kształtem europejskiego systemu finansowego silnie łączy się z dorobkiem teoretycznym nauk ekonomicznych. W dyskusję nad reformą rynku usług finansowych UE, wpisuje się bardzo dobrze tematyka związana $z$ analizą i typologią systemów finansowych na świecie. Studia porównawcze dotyczące różnych modeli systemów finansowych, w szczególności wad i zalet kredytu bankowego $\mathrm{w}$ porównaniu $z$ finansowaniem bezpośrednim przez rynki finansowe, to ważny i obszerny dział nauki o finansach (Levine, 2001; Allen i Gale, 2001). Tego rodzaju analizy są także elementem studiów komparatystycznych nad modelami kapitalizmu we współczesnych gospodarkach (Amable, 2003; Hall i Soskice, 2001). Teoria ta dostarcza narzędzi do analizy nowych regulacji oraz badań nad tym, jak będzie wyglądać instytucjonalna zmiana $w$ sektorze finansowym UE oraz jakie trudności mogą się pojawić.

\section{Kształt i założenia CMU oraz ekonomiczne tło projektu}

CMU jest obecnie, poza unią bankową, jednym $z$ najistotniejszych projektów regulacyjnych, skierowanych do sektora finansowego 
w Europie (EC, 2015d). Pełne wprowadzenie nowych rozwiązań jest planowane na 2019 rok.

Najważniejszymi obszarami reform, które Komisja Europejska (KE, European Commission - EC) zamieściła w Zielonej Księdze dotyczącej CMU są (EC, 2015c):

- poprawa dostępu europejskich przedsiębiorstw do długoterminowego finansowania, głównie w przypadku start-upów oraz małych i średnich przedsiębiorstw (MSP); - zwiększenie różnorodności (dywersyfikacja) dostępnych dla firm metod finansowania poprzez rozwój kapitałowych rynków instrumentów właścicielskich (akcji), a także korporacyjnych instrumentów dłużnych.

Przed projektem CMU postawiono trzy podstawowe cele (EC, 2015a):

- zwiększenie dostępności niebankowych źródel finansowania,

- pogłębienie integracji $\mathrm{w}$ zakresie usług finansowych,

- wsparcie wzrostu gospodarczego i stabilności finansowej.

W szerszym kontekście, celem CMU jest zwiększenie efektywności europejskich rynków finansowych, a tym samym ułatwienie połączenia potencjalnych inwestorów z przedsiębiorcami - innowatorami, którzy mogą zapewnić wysoką stopę zwrotu $z$ inwestycji w ich przedsięwzięcia (EC, 2015c).

W dokumentach UE poświęconych CMU (EC, 2015a; 2015b; 2015c), podkreśla się fakt, że w porównaniu ze Stanami Zjednoczonymi, europejski sektor MSP pozyskiwał pięciokrotnie mniej finansowania z rynków kapitałowych. Na podstawie kalkulacji przeprowadzonych przez analityków KE wskazano, że gdyby rynek funduszy venture capital był na podobnym etapie rozwoju, jak w Stanach Zjednoczonych, mógłby dostarczyć do europejskich przedsiębiorstw dodatkowe 90 mld EUR w latach 2010-2015. Ponadto, wznowienie transakcji sekurytyzacyjnych oraz zwiększenie ich wolumenu do poziomu stanowiącego połowę wartości odnotowanej przed kryzysem subprime, oznaczałoby dodatkowe zasilenie przedsiębiorstw na kwotę 100 mld EUR, z czego 20 mld EUR dotyczyłoby sektora MSP. Analizując kalkulacje przeprowadzone przez KE można odnieść wrażenie, że rozwój rynków finansowych (metod finansowania bezpośredniego gospodarki), byłby bardzo dobrym rozwiązaniem i mógłby przyczynić się do przyspieszenia wzrostu gospodarczego w Europie.

$Z$ punktu widzenia stabilności europejskiego systemu finansowego, CMU otwiera możliwość wspomnianej już dywersyfikacji metod finansowania inwestycji przez przedsiębiorców. Dzięki temu, w przypadku problemów sektora bankowego, mógłby działać alternatywny kanał, oparty o rynki kapitałowe. Podniesienie znaczenia rynków finansowych ma w założeniach doprowadzić do zwiększenia ilości kapitału dla przedsięwzięć inwestycyjnych, w obliczu zagrożenia potencjalnym ograniczeniem akcji kredytowej przez sektor bankowy (EC, 2015c).

Silna zależność systemu gospodarczego od kredytu bankowego i trudności w dostępie do alternatywnych źródeł finansowania stanowią, co do zasady, słabość danego państwa. Przykładem potwierdzającym to stwierdzenie jest historia kryzysu, który rozpoczął się w 1997 roku we wschodzących gospodarkach azjatyckich. Monokultura systemów finansowych państw takich, jak: Korea Południowa, Filipiny, czy Malezja, uniemożliwiła efektywną transformację oszczędności i sprzyjała otwarciu się na krótkoterminowe inwestycje (hot money), a po wybuchu kryzysu uczyniła jego skutki bardziej dotkliwymi. Zabrakło alternatywnych (innych, niz kredyt bankowy) źródeł finansowania inwestycji i tym samym powrót na ścieżkę wzrostu okazał się trudniejszy (Hack i Close, 2013; Bhattacharyay, 2011). A. Greenspan (1999), określił w tym czasie rynki kapitałowe mianem koła zapasowego gospodarki (spare tire). Słowa: „The lack of a spare tire is of no concern if you do not get a flat. East Asia had no spare tires" wypowiedziane zostały w kontekście kryzysu finansowego w Azji Południowo-Wschodniej. Nie ulega wątpliwości, że również dzisiaj, zarówno w przypadku państw rozwiniętych, jak i rozwijających się, posiadanie zdywersyfikowa- 
nego i zrównoważonego systemu finansowego, stanowi kluczowy element otwierający drogę do stabilnego wzrostu w długim okresie.

$Z$ kolei ostatni, globalny kryzys bankowy, który w części państw doprowadził do kryzysu finansowego, uwypuklił słabości europejskiego modelu finansowania. Zbytnia zależność wielu państw europejskich od sektora bankowego implikowała szereg niekorzystnych zjawisk. Na wykresie 1. zostały przedstawione aktywa banków krajowych $w$ relacji do PKB w wybranych państwach w 2014 roku. Dostrzegalna jest wyraźna dysproporcja udziału krajowego sektora bankowego w PKB między USA a państwami Zachodniej Europy. W Stanach Zjednoczonych udział ten oscylował wokół $50 \%$, w państwach Europy Zachodniej wskaźnik ten przekraczał poziom $300 \%$. Wysoki udział sektora bankowego w PKB w Wielkiej Brytanii może budzić wątpliwości, co do zasadności klasycznego podziału państw na zorientowane bankowo (Europa Kontynentalna) i oparte o rynek kapitałowy (kraje anglosaskie).

Taki model finansowania podmiotów gospodarczych wywołał negatywne skutki. Jednym $z$ nich były wysokie koszty dokapitalizowania sektora bankowego, w których partycypowały władze centralne. W ten sposób powstawało sprzężenie między kryzysem sektora bankowego a problemami sektora finansów publicznych (Noyer, 2012). Dodatkowo, nadmierne uzależnienie przedsiębiorstw od finansowania bankowego, utrudniało MSP pozyskiwanie alternatywnych źródeł finansowania, a to z kolei ograniczało możliwość inwestycji i pogłębiało spowolnienie gospodarcze. Szacuje się, że na skutek kryzysu, wartość inwestycji w UE spadła o około $10 \% \mathrm{w}$ stosunku do przedkryzysowego 2007 roku (EC, 2015a).

Istotną nauką, płynącą $z$ doświadczeń gospodarek europejskich nabytych podczas kryzysu jest wniosek, że dla zapewnienia stabilności systemu, konieczna jest dywersyfikacja źródeł finansowania (EC, 2017; Langfield i Pagano, 2016). Rynek kapitałowy może stanowić dodatkowy bufor pozwalający efektywniej absorbować szoki. Ponadto, w państwach o większym udziale finansowania rynkowego, proces wychodzenia $z$ kryzysu następował zazwyczaj szybciej (Allard i Blavy, 2011; Grjebine i in., 2014). Zwiększenie roli rynków kapitałowych, pozwala także na dywersyfikację inwestorów, zwłaszcza zagranicznych, co łagodzi potencjalne, negatywne konsekwencje kryzysu wewnętrznego. Trudno natomiast jednoznacznie rozstrzygnać, czy lepszym modelem finansowania przedsiębiorstw transmisji kapitału między oszczędzającymi (inwestorami) a innowatorami (przedsiębiorcami) - jest model oparty o kredyt bankowy (jak w większości państw Europy Kontynentalnej), czy też model związany $z$ rynkami kapitałowymi (jak w krajach anglosaskich). Wyniki dotychczasowych badań nie potwierdziły jednoznacznie tezy o ewentualnej wyższości jednego rozwiązania nad drugim, co powinien wziąć pod uwagę ustawodawca przy kształtowaniu reform systemu finansowego (Beck i Levine, 2002). $Z$ tego też względu, niektórzy uczestnicy życia gospodarczego przestrzegają przed nadmiernym importem modelu anglosaskiego do porządku europejskiego (WSBI i ESBG, 2015). Brak dywersyfikacji i swego rodzaju monokultura w tym zakresie, nie są jednak korzystne. Ponadto, CMU nie musi być traktowana, jako próba przeobrażenia systemu finansowego w Europie, a raczej jako projekt zmierzający do uzupełnienia pewnych braków, które dały o sobie znać przy okazji ostatniego, globalnego kryzysu bankowego.

Jednocześnie, spotykany $\mathrm{w}$ literaturze podział modeli finansowania na system anglosaski (oparty o rynek kapitałowy) i kontynentalny (oparty o rynek bankowy), jest poddawany krytyce. Analiza głównych wskaźników opisujących strukturę finansowania gospodarki, często nie pozwala jednoznacznie zakwalifikować danego państwa do jednego $z$ tych modeli. Oba modele w znacznym stopniu opierają się na finansowaniu bankowym, a przez to $\mathrm{w}$ obu przedsiębiorstwa narażone są na ryzyko zacieśniania polityki kredytowej. Przykładowo, w Wielkiej Brytanii, uważanej tradycyjnie za gospodarkę opartą o kapitałowy system finansowania, odnotowano w latach 
2000-2014 jeden $z$ najwyższych poziomów relacji między wartością aktywów sektora bankowego a PKB (wykres 2.). Jednocześnie, w 2015 roku występował w tym państwie stosunkowo niski udział funduszy venture capital w PKB (wykres 3.). Ponadto, w latach 2000-2011 odnotowano także relatywnie niski udział wartości wyemitowanych dłużnych papierów wartościowych przedsiębiorstw w PKB (wykres 4.).

Do ciekawych spostrzeżeń dochodzi B. Scholtens (1997), wskazując, że rozbieżności $\mathrm{w}$ ocenie gospodarek $\mathrm{w}$ znacznej mierze zależą (obok czynników kulturowych) od regulacji finansowych. Jest to pozytywny wniosek w kontekście planowanego projektu reform. Znaczenie regulacji $\mathrm{w}$ ksztaltowaniu finansowania gospodarki pozwala przypuszczać, że obrana przez ustawodawcę unijnego ścieżka, może przynieść pozytywne rezultaty.

\section{Inicjatywy w ramach CMU}

W ramach prac nad CMU zostal przygotowany szczegółowy plan działań (EC, 2015b). Zawiera on pełną listę czynności, które mają zostać podjęte wraz z orientacyjnym terminarzem. Planowane inicjatywy zostały podzielone na sześć głównych grup:

- finansowanie innowacyjności, start-upów oraz firm nienotowanych na giełdzie;

- wprowadzenie ułatwień dla przedsiębiorców w pozyskiwaniu kapitału na rynku publicznym;

- inwestowanie w jakość infrastruktury prawnej;

- wspieranie indywidualnych i instytucjonalnych inwestycji;

- zwiększenie potencjału banków w zakresie finansowania gospodarki;

- wprowadzenie ułatwień w zakresie inwestycji transgranicznych.

W ramach pierwszej grupy, do narzędzi i środków, które mają posłużyć do promowania długoterminowych inwestycji zaliczyć można m.in. (EC, 2015b):

- sugestię stworzenia pan-europejskiego funduszu venture;
- propozycję prac nad zachętami podatkowymi dla tzw. „aniołów biznesu” oraz funduszy podwyższonego ryzyka (inwestujących $w$ innowacyjne i ryzykowne przedsięwzięcia);

- analizę moźliwości rozwoju platform wykorzystujących crowdfunding (jako innowacyjny i niezależny od sektora bankowego sposób finansowania inwestycji).

$\mathrm{Na}$ podstawie danych zamieszczonych na wykresie 3. można uznać, że w 2015 roku znaczenie funduszy venture capital w Europie było znacznie mniejsze, niż w Stanach Zjednoczonych. Oznacza to, że istnieje przestrzeń do rozwijania tego rynku.

Inicjatywy prezentowane $\mathrm{w}$ ramach pierwszej grupy, poza powołaniem funduszu venture, maja, na obecnym etapie, charakter analityczny i nie będą bezpośrednio oddziaływać na rynek finansowy w Europie w najbliższej przyszłości. Fundusz, nad powołaniem którego prace obecnie trwają, ma w założeniach mieć wartość $400 \mathrm{mln}$ EUR, co przy ograniczeniu zaangażowania środków publicznych w projekty inwestycyjne na poziomie $25 \%$, oznacza wzrost inwestycji typu venture w UE o 1,6 mld EUR. Skala tego projektu wydaje się niewielka w zestawieniu $z$ rozmiarem obecnego rynku funduszy private equity i venture capital w Europie. W 2015 roku, środki zebrane przez europejskie fundusze tego typu, wyniosły około 47,5 mld EUR, a aktywa będące pod ich zarządem osiągnęły wartość 564 mld EUR (Invest Europe, 2017). Wydaje się zatem, że główny akcent powinien być położony na udoskonalenie regulacji prawnych, a nie bezpośredni rozwój funduszy $z$ udziałem środków publicznych.

W ramach drugiej grupy inicjatyw, najistotniejsza wydaje się nowelizacja dyrektywy w sprawie prospektu emisyjnego regulującej emisje akcji. W dalszej kolejności wskazano także przegląd możliwości zwiększenia płynności rynku dłużnych papierów przedsiębiorstw oraz wspieranie finansowania poprzez instrumenty właścicielskie, $\mathrm{w}$ ramach propozycji legislacyjnych dotyczących wspólnej, skonsolidowanej podstawy opodatkowania 
osób prawnych (Common Consolidated Corporate Tax Base).

Trzecia grupa inicjatyw obejmuje prace nad dostosowaniem najważniejszych aktów prawnych w UE regulujących funkcjonowanie sektora finansowego (tj. dyrektywy Solvency II oraz Capital Requirements Regulation - CRR), a także przegląd i ocenę zbiorczego wpływu reform na sektor.

Najciekawszymi inicjatywami, podejmowanymi w czwartej grupie są: ocena możliwości stworzenia $w$ UE rynku prostych i efektywnych emerytur indywidualnych oraz eliminacja kluczowych barier dla transgranicznej dystrybucji funduszy inwestycyjnych.

Zwiększenie dostępności emerytur indywidualnych wydaje się istotne $z$ punktu widzenia pobudzenia rozwoju gospodarczego i inwestycji w Europie. Obecne tendencje w Europie Kontynentalnej wskazują, że rynek ten jest słabo rozwinięty (Lannoo i in., 2015, s. 1), co ogranicza zdolność gospodarek do angażowania kapitału długoterminowego, a tym samym negatywnie oddziałuje na ich konkurencyjność i innowacyjność. Na wykresie 5. przedstawiona została wartość rynku funduszy emerytalnych $\mathrm{w}$ relacji do $\mathrm{PKB}$ w wybranych państwach w latach 2000-2014. W państwach, zwyczajowo uznawanych za gospodarki oparte na finansowaniu z rynków kapitałowych (Wielka Brytania, USA), popularność funduszy emerytalnych, wyrażona udziałem wartości rynku do PKB, jest kilkakrotnie większa, niż $\mathrm{w}$ innych, analizowanych państwach europejskich. W tym kontekście oraz $z$ uwagi na: niekorzystne zjawiska demograficzne, presję budżetową $\mathrm{w}$ wielu państwach europejskich oraz niskie stopy procentowe, pobudzenie tego rynku w przyszłości może okazać się konieczne. Istotnym wyzwaniem jest jednak duże zróżnicowanie państw UE w zakresie zabezpieczenia emerytalnego przejawiające się w obecności silnych inwestorów instytucjonalnych (emerytalnych funduszy kapitałowych) oraz dopuszczalnej elastyczności strategii inwestycyjnych tych podmiotów.

W ramach piątej grupy inicjatyw, na uwage zasługuje propozycja wprowadzenia nowych ram w zakresie prostych, przejrzystych i standardowych sekurytyzacji, które pozwoliłyby na zwiększenie dostępności kredytów, obniżenie kosztów finansowania oraz poprawę efektywności poprzez ułatwiony transfer ryzyka.

Szósta grupa obejmuje projekty dotyczące przeglądu barier dla przepływu kapitału, w tym barier podatkowych, a także potrzebę konwergencji przepisów nadzorczych w obszarze rynku finansowego i przepisów upadłościowych. Obecnie, inwestorzy w Europie lokują środki przede wszystkim na rynkach krajowych, co znacznie ogranicza możliwość efektywnej alokacji kapitału i ryzyka w wymiarze międzynarodowym. Harmonizacja i standaryzacja zasad i praktyk rynkowych, może zatem stanowić skuteczny bodziec do zwiększania inwestycji zagranicznych.

Plan działania składa się $z$ trzydziestu trzech inicjatyw. Są one bardzo ambitne, odnoszą się także do szerokiej gamy sposobów oddziaływania na system finansowy: od zmian podatkowych, regulacyjnych, po rozwijanie funduszy $z$ udziałem sektora publicznego. Duży zakres planowanych zmian, pozwala na wyciągnięcie wniosku, że mogą one prowadzić do zmiany "formalnych zasad gry” dla sektora finansowego w UE. „Formalne zasady gry" stanowią drugi poziom instytucjonalnego schematu funkcjonowania gospodarek i społeczeństw według O.E. Williamsona (2000, s. $597)^{1}$.

Zmianom ulegnie otoczenie prawno-regulacyjne systemu finansowego. Konsekwencja wprowadzania zmian, a także poziom ich akceptacji i wiedza podmiotów gospodarujących w UE, przesądzą o tym, czy interwencja prawodawcy rzeczywiście wpłynie na instytucje w gospodarkach Europy Kontynentalnej. Trudno dziś ocenić, czy wielkość finansowania bezpośredniego, opartego o rynki finansowe, zacznie rzeczywiście zrównywać się $z$ „tradycyjnym” kredytem bankowym w pasywach sektora przedsiębiorstw. Należy zwrócić uwagę na fakt, że obszary regulacyjne, które

W ramach nowej ekonomii instytucjonalnej (New Institutional Economics), wyróżnia się cztery poziomy, na których funkcjonują instytucje w gospodarce, tj: nieformalne reguty gry, formalne reguły gry, poziom ładu (zarządczy), poziom ciągłej alokacji zasobów (decyzje podmiotów gospodarujących). 
mają zostać poddane analizom w kontekście celów CMU, charakteryzują się różnym stopniem konwergencji między państwami członkowskimi. Podlegają także harmonizacji prawnej w różnym zakresie. Wprowadzenie daleko idących zmian podatkowych będzie dużo trudniejsze, niż dokonanie zmian $\mathrm{w}$ istniejących aktach prawnych UE dotyczących sektora bankowego. CMU może zatem okazać się projektem trudnym do zrealizowania $w$ tak szerokim zakresie, w jakim jest dotychczas opisywana. Dla spójności reformy, zachowanie szerokiego zakresu jest jednak kluczowe.

\section{CMU a unia bankowa}

CMU jest projektem ambitnym, szerokim, choć $\mathrm{w}$ dalszym ciągu mającym charakter ogólnych zamierzeń. Dostrzegalne jest to zwłaszcza $w$ porównaniu $z$ unią bankową, która, również będąc projektem daleko idącym i złożonym, sprowadza się do trzech sprecyzowanych filarów, tj:: jednolitego mechanizmu nadzorczego (Single Supervisory Mechanism - SSM), jednolitego mechanizmu restrukturyzacji i uporządkowanej likwidacji banków (Single Resolution Mechanism - SRM) oraz systemu gwarancji depozytowych (Deposit Guarrantee Scheme - DGS).

Poza tym, CMU będzie dotyczyć całej UE, podczas, gdy unia bankowa odnosi się jedynie do strefy euro, z możliwością rozszerzenia o inne państwa. Włączenie państwa spoza strefy euro do unii bankowej, jest jednak oceniane, jako niekorzystne (Pisany, 2016b). Polska, jako państwo członkowskie UE, jest uczestnikiem unii kapitałowej z mocy prawa UE, w przeciwieństwie do unii bankowej. Zatem skutki unii kapitałowej, będą dotyczyć polskiej gospodarki bezpośrednio.

Różnica zadań postawionych przed projektami obu unii, determinuje także odmienny ich charakter. Podczas, gdy celem unii bankowej było zwiększenie bezpieczeństwa i stabilności finansowej oraz eliminacja nadużyć w sektorze, CMU ma na celu wspieranie rozwoju gospodarczego. $Z$ tego też względu, zadaniem CMU jest usuwanie barier regulacyjnych i ograniczeń transgranicznego rozwoju rynku, w przeciwieństwie do unii bankowej nakładającej na sektor bankowy szereg dodatkowych obowiązków.

K. Waliszewski (2015, s. 128), ocenia unię bankową oraz kapitałową jako projekty komplementarne ze względu na potencjalnie kluczową rolę banków w rozwijaniu finansowania bezpośredniego, opartego na rynkach finansowych. Duże, uniwersalne banki, zwłaszcza w systemie bankowo-centrycznym, takim, jak system kontynentalny, są podmiotami, które moga pełnić funkcje organizatorów emisji, pośredników, ale także gwarantów, czy wreszcie nabywców i samych emitentów. Traktowanie CMU, jako importowanego modelu anglosaskiego, nie jest więc uzasadnione.

W tym kontekście, unia kapitałowa uznana może być za czynnik zachęcający do rozszerzenia modelu biznesowego europejskich banków. W ten sposób bilanse banków mogą zostać zwiększone, co prawdopodobnie uczyni banki jeszcze bardziej istotnymi systemowo, a także skomplikuje model biznesowy. Może to utrudnić efektywny nadzór sektora bankowego. Teza o komplementarności sektora bankowego i kapitałowego nie jest w pełni słuszna. Konkurencja między tymi rynkami, przejawia się z jednej strony $w$ poszukiwaniu projektów inwestycyjnych, które mogłyby podmioty funkcjonujące na owych rynkach sfinansować. $Z$ drugiej zaś, w rywalizacji o źródła finansowania działalności podmiotów rynku bankowego i kapitałowego. Efektem CMU może być transfer środków gospodarstw domowych $z$ lokat bankowych do rynku kapitałowego. Proces ten, prawdopodobnie wzmożony $\mathrm{w}$ warunkach utrzymujących się niskich stóp procentowych, może negatywnie oddziaływać na zdolność banków do kredytowania gospodarki.

Wraz z rozwojem rynków kapitałowych, zwiększyć się może również stopień powiązań między podmiotami systemu finansowego, zarówno w wymiarze międzysektorowym (np. związki między sektorem bankowym a rynkami kapitałowymi), jak i transgranicznym. Rosnąca współzależność sektorów i instytucji finansowych, przyczynić się może do łatwiejszego rozprzestrzenia się problemów 
między uczestnikami systemu finansowego, a w konsekwencji może częściowo ograniczyć pozytywne skutki, związane $z$ dywersyfikacją finansowania.

\section{Zakończenie}

CMU to projekt ważny i godny uwagi, ze względu na swój zakres. Diagnoza problemów i wyzwań, którym będzie musiała sprostać UE, przedstawiona $\mathrm{w}$ dokumentach analitycznych dotyczących CMU, jest jak najbardziej trafna. Efektywny, zdywersyfikowany system finansowy, a tym samym odporny na potencjalne wstrząsy, jest warunkiem koniecznym uwolnienia inwestycji oraz podniesienia poziomu innowacji w Europie.

Selektywne sięganie do doświadczeń państw anglosaskich w tym zakresie, wydaje się uzasadnione, tym bardziej, że analizy ilościowe wskazują na dużą przestrzeń dla rozwoju rynków finansowych w UE. Warto jednak zwrócić uwagę na potencjalne trudności, które może napotkać ten projekt. $\mathrm{W}$ badaniach związanych $z$ komparatystyką systemów kapitalistycznych, a w szczególności przeprowadzonych przez B. Amable (2003), została podkreślona rola komplementarności poszczególnych instytucji, w różnych obszarach życia gospodarczego. Przykładem relacji komplementarnej, która wyznacza stopień instytucjonalnej jakości danego systemu gospodarczego, może być połączenie, w ramach jednego państwa, systemu emerytalnego, opartego o inwestycje kapitałowe i zasadę zdefiniowanej składki, $z$ silnie rozwiniętym rynkiem finansowym (akcji i obligacji), jako źródłem finansowania przedsiębiorstw. Takie zestawienie generuje długoterminowy popyt na ewentualne emisje papierów wartościowych przedsiębiorstw. Innym przykładem tego typu relacji, może być powiązanie systemu szkolnictwa $z$ systemem finansowym. Współzależności te są często analizowane przy użyciu prostych schematów teorii gier (Pisany, 2016a, s. 70).

W odniesieniu do CMU, zróżnicowanie gospodarek UE, choćby $\mathrm{w}$ przypadku systemów emerytalnych, może stanowić duże wyzwanie dla prawodawcy. Rozwój bezpośrednich form finansowania przedsiębiorstw, będzie trudniejszy w niektórych państwach, ze względu na ich schemat instytucjonalny i jakość instytucji, a także poziom świadomości ekonomicznej przedsiębiorstw i gospodarstw domowych. Perspektywa wynikająca ze studiów porównawczych nad systemami gospodarczymi, realizowana $\mathrm{w}$ ramach nowej ekonomii instytucjonalnej, jest zatem potrzebna $w$ głębszym zrozumieniu wyzwania związanego z CMU, w tym potencjalnych ograniczeń i trudności stojących przed unijnym prawodawstwem.

Z projektem CMU związanych jest szereg wyzwań, które mogą utrudnić efektywną implementację jego założeń. Ostatecznie jednak, szeroki zakres projektowanej unii jest warunkiem powodzenia projektu. CMU obejmuje swym zasięgiem nie tylko stronę podażową, ale także stronę popytową. Może także przyczynić się do transferu oszczędności do rynku kapitałowego, tym samym uwolnienia środków na inwestycje. W literaturze podkreślony został fakt, że tylko kompleksowe oddziaływanie na rynek, poprzez komplementarne reformy, może przyczynić się do trwałego osiągnięcia nowego, pożądanego poziomu równowagi.

CMU należy ocenić, jako ważną i potrzebną inicjatywę regulacyjną. Obecnie jest ona na zbyt wczesnym etapie rozwoju, aby oceniać szanse jej powodzenia. Część inicjatyw ogranicza się tylko do projektów analityczno-badawczych. Z kompleksową oceną, należy poczekać do przedstawienia konkretnych propozycji legislacyjnych. Nie ulega natomiast wątpliwości, że pełna realizacja CMU, wymagałaby pogłębienia integracji, co w obecnych warunkach politycznych, wydaje się niestety trudne.

\section{Bibliografia}

Allard, J., i Blavy, R. (2011). Market phoenixes and banking ducks. Are recoveries faster in market-based financial systems? IMF Working Paper, 11(213). doi:10.5089/9781463902292.001.

Allen, F., i Gale, D. (2001). Comparing financial systems. Cambridge: MIT Press. 
Amable, B. (2003). The diversity of modern capitalism. Oxford: Oxford University Press.

Beck, T., i Levine, R. (2002). Industry growth and capital allocation: does having a market- or bank-based system matter? Journal of Financial Economics, 64(2). doi:10.1016/ S0304-405X(02)00074-0.

Bhattacharyay, B.N. (2011). Bond market development in Asia: an empirical analysis of major determinants. ADBI Working Paper, 300. doi:10.2139/ssrn.1898047.

EBC. (2017). Pobrane 06.05.2017 z https://www. ecb.europa.eu.

EC. (2015a). Commission staff working document. Economic analysis accompanying the document: Communication from the Commission to the European Parliament, the Council, the European Economic and Social Committee and the Committee of the Regions: Action plan on building a Capital Markets Union (SWD(2015) 183 final).

EC. (2015b). Communication from the Commission to the European Parliament, the Council, the European Economic and Social Committee and the Committee of the Regions: Action plan on building a Capital Markets Union (COM(2015) 468 final).

EC. (2015c). Green Paper: Building a Capital Markets Union (COM (2015) 63 final).

EC. (2015d). Updated version of first memo published on 15/04/2014 - Banking Union: restoring financial stability in the Eurozone. Pobrane 06.05.2017 $z$ http://europa.eu.

EC. (2017). Remarks on the progress of the Capital Markets Union. Pobrane 04.05.2017 z http:// europa.eu.

FED. (2017). Pobrane 06.05.2017 $z$ https://www. federalreserve.gov.

Greenspan, A. (1999). Do efficient financial markets mitigate financial crises? Speech at Financial Market Conference of the Federal Reserve Bank of Atlanta. Pobrane 06.05.2017 z https:// www.federalreserve.gov.

Grjebine, T., Szczerbowicz, U., i Tripier, F. (2014). Corporate debt structure and economic recoveries. CEPII Working Paper, 19.

Hack, M., i Close, C. (2013). East Asian corporate bond markets. Bulletin of Reserve Bank of Australia, 3.

Hall, P.A., i Soskice, D. (2001). An introduction to varieties of capitalism. W: P.A. Hall, i D. Soskice (red.), Varieties of capitalism: the institutional foundations of comparative advantage. Oxford: Oxford University Press.

Invest Europe. (2017). Pobrane 08.05.2017 z https://www.investeurope.eu.
Langfield, S., i Pagano, M. (2016). Bank bias in Europe: effects on systemic risk and growth. Economic Policy, 31(85). doi:10.1093/epolic/ eiv019.

Lannoo, K., Pollack, A., i Staehr, O. (2015). Keep capital markets union simple. ECMI Commentary, 38.

Levine, R.E. (2001), Bank-Based or Market-Based Financial Systems: Which is Better? Journal of Financial Intermediation, 11(4). doi:10.1006/ jfin.2002.0341.

Mączyńska, E. (2015). Potencjał rozwojowy Polski w kontekście hipotezy o nowej sekularnej stagnacji. Zeszyty Naukowe Uniwersytetu Szczecinskiego. Finanse. Rynki finansowe. Ubezpieczenia, 854(73).

Noyer, C. (2012). It was vital to break the adverse feedback loop between bank and sovereign risk. Les Echoes, 17.10.2012.

OECD. (2017). Pobrane 08.05.2017 z http://www. oecd.org.

Pichelmann, K. (2015). When 'Secular Stagnation' meets Piketty's capitalism in the 21st century. Growth and inequality trends in Europe reconsidered. European Economy - Economic Papers, 551.

Pisany, P. (2016a). Comparative models of capitalism in the areas of financial system and corporate governance - the diversity of capitalism approach perspective. International Journal of Management and Economics, 52.

Pisany, P. (2016b). Jednolity Mechanizm Nadzorczy jako odpowiedź na kryzys bankowy - analiza ze szczególnym uwzględnieniem przypadku Polski. W: I. Pietryka (red.), Problemy Gospodarki Światowej. Toruń: Polskie Towarzystwo Ekonomiczne Oddział w Toruniu, Instytut Badań Gospodarczych.

Scholtens, B. (1997). Bank- and market-oriented financial Systems: fact or fiction, BNL Quarterly Review, 50(202).

Traktat o funkcjonowaniu Unii Europejskiej (wersja skonsolidowana) (Dz.Urz. UE C 202 $z$ 7.6.2016).

Waliszewski, K. (2015). Unia Bankowa i Unia Rynków Kapitałowych - analiza porównawcza europejskich projektów integracyjnych $\mathrm{w}$ obszarze finansowym. Nauki o Finansach. Financial Sciences, 2(23). doi:10.15611/nof.2015.2.07.

Williamson, O.E. (2000). The New Institutional Economics: taking stock, looking ahead. Journal of Economic Literature, 38(3). doi: 10.1257/ jel.38.3.595.

World Bank. (2017). Pobrane 08.05.2017 z http:// www.worldbank.org. 
WSBI, i ESBG. (2015). Financial systems in Europe in the US: structural differences where banks remain the main source of finance for companies. Pobrane 09.05.2017 z https://www.wsbi-esbg.org.

Informacje uzupełniające

Wkład autorski: autorzy zaakceptowali ostateczną wersję artykułu. Ich wkład w powstanie artykułu jest następujący: P.P. opracował koncepcję i plan artykułu, P.P. i W.D zebrali dane, przeanalizowali i zinterpretowali dane oraz przygotowali szkic artykułu, W.D. krytycznie zrewidował artykuł pod kątem istotnej zawartości intelektualnej. 


\section{Aneks}

Wykres 1.

Wartość aktywów banków krajowych w relacji do PKB w wybranych państwach w 2014 roku (w \%) 400

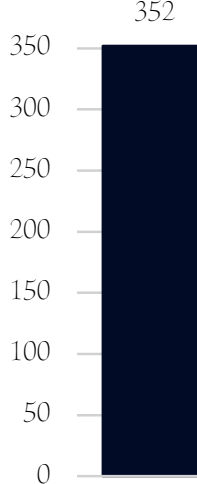

Szwecja
352

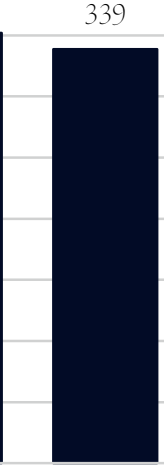

Wielka

Brytania

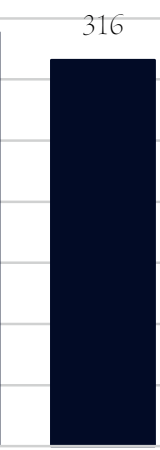

Francja

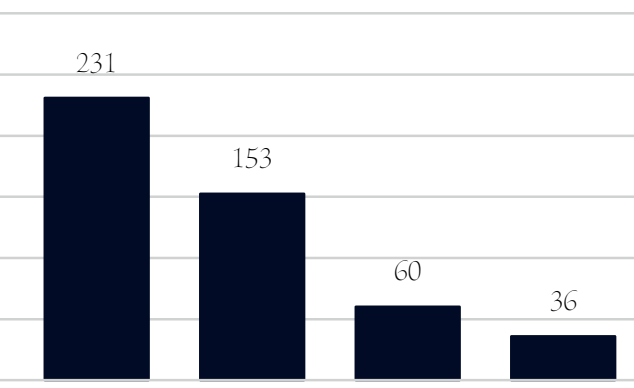

Niemcy Włochy
Stany

Zjednoczone

Źródło: Opracowanie własne na podstawie EBC (2017) i FED (2017).

Wykres 2.

Kapitalizacja rynku akcyjnego w relacji do PKB w wybranych państwach w latach 2000-2014 (w \%)

200

150

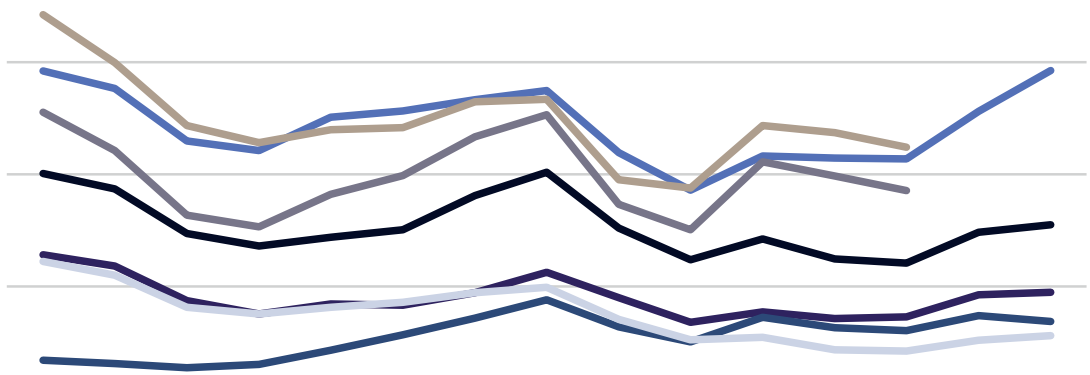

0

200020012002200320042005200620072008200920102011201220132014

Francja

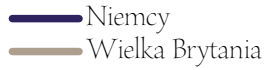

Polska

Włochy

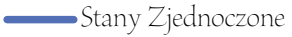

Źródło: Opracowanie własne na podstawie World Bank (2017). 
Wykres 3.

Udział funduszy venture capital w relacji do PKB w wybranych państwach w 2015 roku (w \%)

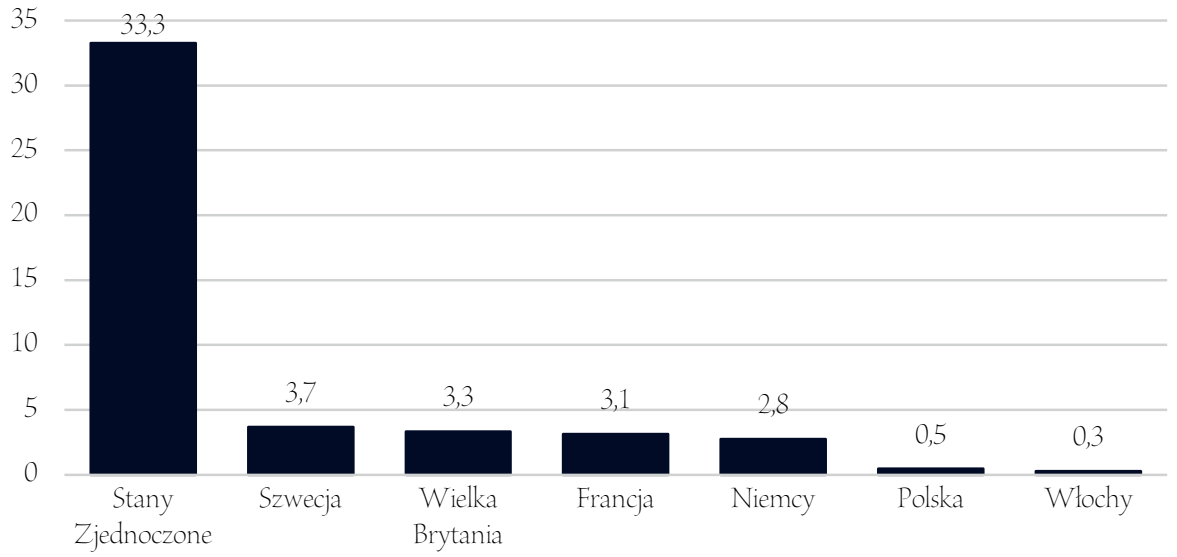

Źródło: Opracowanie własne na podstawie OECD (2017)

Wykres 4.

Wartość rynku dłużnych papierów wartościowych przedsiębiorstw $\mathrm{w}$ relacji do PKB w wybranych państwach w latach 2000-2011 (w\%)

80

60

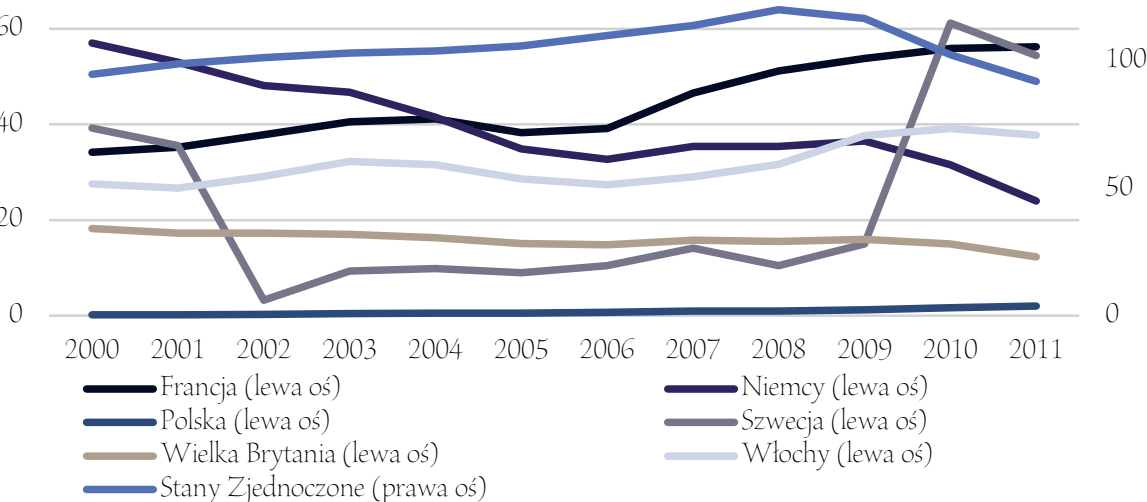

Źródło: Opracowanie własne na podstawie World Bank (2017). 


\title{
Wykres 5.
}

Wartość rynku funduszy emerytalnych w relacji do PKB w wybranych państwach w latach 2000-2014 (w\%) 30

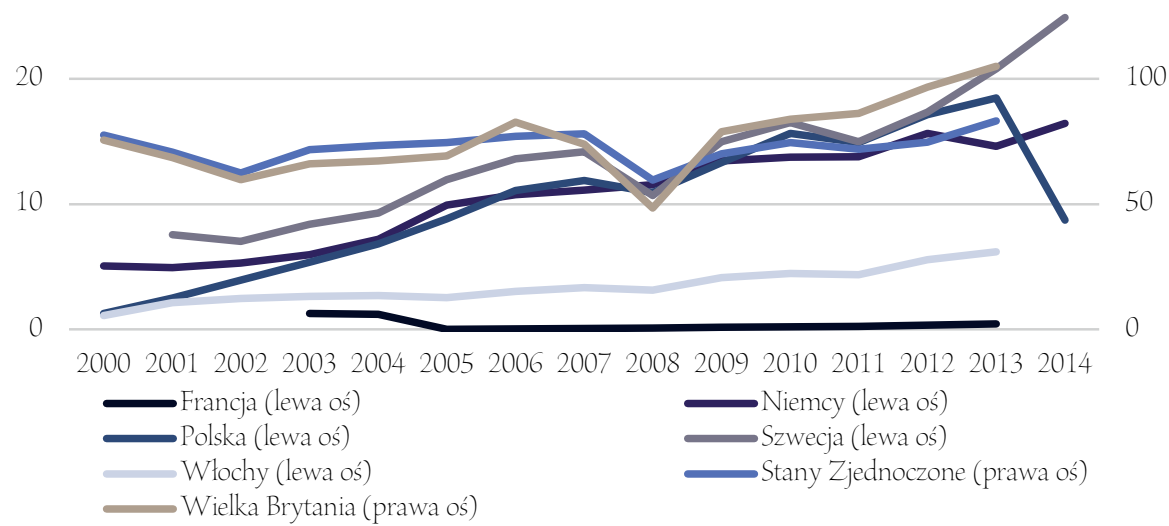

Źródło: Opracowanie własne na podstawie World Bank (2017).

Capital Markets Union and differentiation of financial systems in member states

\begin{abstract}
Motivation: The European Capital Market Union (CMU) is a comprehensive initiative with an aim to support the competitiveness of the European Union (EU) economy. Its main tasks are to improve the access for European enterprises to long-term financing, especially in case of small and medium enterprises (SMEs) and start-up companies as well as broadening the variety of financing sources thanks to the development of equity and corporate bonds markets.

Aim: The main aim of the article is to present the CMU in the light of the literature related to structural changes in financial systems and in the context of current shape of the European financial sector. As a result, the assessment of $\mathrm{CMU}$ and main potential obstacles, the EU lawmakers may encounter are presented.

Results: The scope of the reform is a major challenge in terms of regulatory (different degree of harmonization of different law branches in the EU) and political issues (related to deepening of the integration among EU countries) and due to financial systems diversity in the EU countries. However, according to economic researches on institutional complementarity, among others B. Amable (2003), the scope of effective regulation must be broad and embrace both demand and supply side of the market. Deriving conclusions from Anglo-Saxon countries' experiences with market-based economy seems to be reasonable in this case, especially taking into consideration still non-saturated market for this type of financing in the EU.
\end{abstract}

Keywords: capital market; regulations; European Union

JEL: G15; G18 
